\title{
Strategi public relations Sinar Mas Land dalam membangun brand image perusahaan
}

\author{
Melita Yosephine ${ }^{1}$, Anisa Diniati \\ 1) Institut Teknologi dan Bisnis Kalbis, Jakarta, Indonesia \\ 2) Universitas Telkom, Bandung, Indonesia
}

\begin{abstract}
ABSTRAK
Pertumbuhan ekonomi dan pesatnya pengembangan kota di Indonesia, membuat industri properti semakin berkembang. Konsumen akan memutuskan secara teliti, properti mana yang akan dipilih dan dibeli. Sinar Mas Land sebagai industri properti yang menjadi perhatian masyarakat dan media memperkenalkan perusahaannnya dengan cara melakukan proses branding melalui peran Public Relations (PR). Brand image yang positif penting untuk diupayakan oleh setiap perusahaan, karena kesadaran dan loyalitas konsumen dapat dibangun melalui proses ini. Penelitian ini bertujuan untuk mengetahui strategi public relations Sinar Mas Land dalam membangun brand image perusahaan dan besar harapan hasil penelitian dapat menjadi indikator keberhasilan bagi para pebisnis di industri serupa. Penelitian ini menggunakan paradigma postpositivisme, pendekatan kualitatif, dan jenis penelitian deskriptif. Teknik pengumpulan data diperoleh dengan melakukan wawancara mendalam, observasi, studi kepustakaan, dan studi dokumen. Hasil penelitian ini menujukkan bahwa Sinar Mas Land berhasil menggunakan strategi PR dengan melakukan riset, brainstorming, analisis SWOT, menentukan key public dalam fase formative research. Dalam fase strategi Sinar Mas Land menentukan tujuan dan sasaran program, melakukan aksi publikasi melalui event dan aksi joint venture perusahaan. Pada tahap taktik Sinar Mas Land melakukan bonding wartawan, pendekatan publik, monitoring konten media, mempersiapkan media baru. Setelah itu tahap akhir dilakukan dengan melakukan pra evaluasi, evaluasi internal dan evaluasi eksternal pada fase penelitian evaluatif.
\end{abstract}

Kata-kata Kunci: Brand image; citra; Sinar Mas Land; public relations; strategi

\section{Public Relations strategy of Sinar Mas Land in developing company's brand image}

\begin{abstract}
Economic growth and the rapid development of cities in Indonesia have made the property industry grow. Consumers will carefully decide which property to choose and buy. Sinar Mas Land is a property industry that has caught the media and public's attention and introduces its company by conducting a branding process through public relations (PR). A positive brand image is essential for every company to strive as consumer awareness and loyalty can be built through this process. This study aims to determine the public relations strategy of Sinar Mas Land in developing its brand image and that the research results can be an indicator of success for business people in similar industries. This research uses the postpositivism paradigm, qualitative approach, and descriptive research type. Data collection techniques are obtained through in-depth interviews, observation, literature study, and document study. The results of this study indicate that Sinar Mas Land has successfully used the PR strategy by conducting research, brainstorming, SWOT analysis, determining key publics in the formative research phase. In the strategy phase, Sinar Mas Land determines program goals and objectives, carries out publicity actions through events and corporate joint venture actions. At the tactical stage, Sinar Mas Land carried out journalist bonding, public approach, monitoring media content, and preparing new media. The final stage is carried out by conducting preevaluation, internal evaluation, and external evaluation in the evaluative research phase.
\end{abstract}

Keywords: Brand image; image; Sinar Mas Land; public relations; strategy

Korespondensi: Melita Yosephine, S.I.Kom., Institut Teknologi dan Bisnis Kalbis, Jl. Pulomas Selatan Kav. 22, Jakarta Timur 13210,Email: melitayosephine@gmail.com 


\section{PENDAHULUAN}

Sebagai aset strategi, merek mampu menciptakan nilai dan manfaat tersendiri bagi perusahaan dan konsumennya (Tjiptono, 2014). Berbagai potensi dan manfaat yang dapat merek berikan kepada perusahaan di antaranya adalah sarana menciptakan makna unik dan aosisasi, sumber kompetitif yang unggul, perlindungan hukum, memudahkan orang mengidentifikasi sebuah produk, menunjukkan tingkat kualitas, hingga keuntungan finansial. Oleh karena itu, setiap perusahaan membutuhkan brand sebagai pembeda dengan atribut produk milik kompetitor lain. Sementara itu, bagi para pelanggan, brand memiliki nilai untuk memudahkan mereka dalam mengambil keputusan ketika memilih sebuah produk (Swasty, 2016).

Sinar Mas Land merupakan perusahaan yang bergerak di industri properti yang paling banyak mendapatkan perhatian media. Hal ini dapat dilihat pada jumlah liputan media sebanyak 2.485 pada tahun 2018. Liputan tersebut banyak membahas kontribusi Sinar Mas Land pada negara, mulai dari pembangunan mereka terhadap Gedung pusat perbelanjaan hingga fasilitas umum ruang terbuka hijau berkelas internasional. Pemberitaan tersebut mendirong tumbuhnya kepercayaan konsumen pada perusahaan.

Dalam konteks kesetian merek (brand loyalty), kepercayaan merupakan bagian yang penting. Hal tersebut karena kepercayaan dapat mendorong pelanggan untuk terus menggunakan produk dari perusahaan (repeat buying). Selain itu, pelanggan juga dapat memberikan rekomendasi pembelian produk ke pelanggan lainnya (recommended buying) (Susilowati \& Sumarto, 2010).

Akan tetapi, pada saat yang bersamaan, Sinar Mas Land juga mendapatkan stigma negatif berupa perusahaan yang mayoritas karyawannya chinesse sehingga perusahaan dijuluki dengan citra terlalu chinesse dan dikenal sebagai perusahaan yang berada dikawasan elite seperti di kawasan BSD City. Head of Public Relations Atikah Sunarya menyatakan bahwa persepsi tersebut hadir karena belum adanya strategi merek yang efektif. Hingga pada akhirnya pada tahun 2011, pemilik perusahaan sepakat untuk membentuk sub-divisi Public Relations dan Media Relations di bawah naungan divisi Corporate Communications.

Divisi Public Relations (PR) berperan dalam membangun citra positif perusahaan dan menghapus citra negatif. Citra sendiri merupakan sudut pandang orang lain dalam menilai seseorang, komite, aktivitas hingga sebuah perusahaan (Soemirat \& Ardianto, 2010). Sinar Mas Land melakukan pendekatan kepada masyarakat guna memperbaiki citra negatif tersebut. Pendekatan tersebut dilakukan 
melalui berbagai event yang dibutuhkan oleh masyarakat. Divisi PR melakukan riset untuk mengidentifikasi kebutuhan tersebut agar tepat sasaran.

Untuk membuat masyarakat memutuskan pilihannya pada Sinar Mas Land, maka Public Relations perusahaan menyusun strategi untuk itu. Strategi tersebut dikembangkan oleh stakeholder internal dan eskternal yang tentu mereka memiliki peranan penting dalam memajukan visi dan misinya. Public Relations merupakan pemangku kepentingan internal yang berperan dalam membangun reputasi. Sementara itu, pemerintah, masyarakat, dan media merupakan pemangku kepentingan eksternal perusahaan.

Dalam sebuah perusahaan, Public Relations berperan penting untuk menjalin komunikasi dengan publik internal maupun eksternalnya. Hal ini bertujuan untuk mempersuasi masyarakat selaku penerima pesan mulai dari aspek kognitif, afektif hingga konatif hingga menjaga hubungan baik dengan masyarakat, pemerintah hingga media massa. Dengan demikian, Public Relations perusahaan perlu merancang strategi dengan baik sebagai pedoman mereka dalam menjalankan berbagai program sesuai tujuan yang telah ditetapkan. Dengan rancangan startegi yang baik, maka pesan dalam merek pun dapat tersampaikan dengan baik kepada para konsumen.
Pemaparan di atas juga menunjukkan bahwa upaya perusahaan dalam membangun brand image penting untuk dilakukan. Brand image adalah sebagai tempat penyimpanan nilai bagi perusahaan (Wijaya, 2009). Melalui nama merek, secara tidak langsung perusahaan telah menginvestasikan nilai perusahaan mereka melalui akumulasi biaya iklan dan peningkatan kualitas produk. Investasi nilai perusahaan tersebut dapat dianggap juga sebagai modal jangka panjang untuk menjadikan ide pemasaran yang strategis menjadi sebuah keunggulan kompetitif.

Berbagai program yang dirancang dan diselenggarakan oleh Public Relations perusahaan memperoleh sambutan yang baik hingga dapat diterima dengan antusias oleh publik. Salah satu event yang pernah peneliti ikuti adalah Press Bonding dengan berbagai media dengan acara nonton bareng jurnalis pada saat piala FIFA World Cup yang ke-21 pada bulan agustus 2018. Keberhasilan ini membuat peneliti semakin tertarik untuk melakukan riset terkait strategi yang mereka rancang dan terapkan.

Press bonding sendiri merupakan kegiatan rutin yang dilakukan oleh Sinar Mas Land agar tercipta hubungan harmonis dengan stakeholder eksternal, khususnya media massa. Bentuk dari kegiatan ini adalah nonton bareng jurnalis dengan membangun suasana yang 
menyenangkan dan tentu media yang diundang mendapatkan pelayanan maksimal seperti menyediakan ruangan yang nyaman di hotel mewah, santapan lezat, hingga menyediakan voucher dan hadiah menarik lainnya.

Membangun kedekatan dengan media merupakan salah satu strategi yang diterapkan guna medukung perusahaan dalam menyebarkan informasi kepada publik. Selain itu, mereka juga merancang program selama satu tahun dan melakukan kegiatan publikasi sebagai bentuk soft selling guna menjalin hubungan baik dengan pers. Kegiatan soft selling sendiri merupakan kegiatan komunikasi perusahaan kepada pihak eksternal untuk memberikan nilai-nilai dari brand. (Okazaki, Mueller, \& Taylor, 2010). Biasanya pendekatan ini diterapkan dengan tujuan memberikan pesan secara tersirat, seperti mengemukakan berbagai cerita inspiratif dengan pendekatan emosional. Melalui pendekatan ini, tentu tujuannya bukan untuk membujuk konsumen melakukan pembeliaan pada saat itu, namun calon konsumen dipengaruhi untuk memikirkan nilai-nilai positif yang akan mereka dapatkan saat membeli produk tersebut.

Untuk mensukseskan event, campaign, dan launching product sebagai wadah penyampaian informasi kepada publik, Public Relations perusahaan berusaha menyusun dan menerapkan strategi PR dengan baik.
Keberhasilan dari strategi yang mereka buat dapat terlihat jelas dari besarnya dukungan dan partisipasi stakeholder internal dan eksternal pada berbagai acara tersebut. Selain itu, konten promosi yang kratif dan menarik; kemampuan PR dalam menjalin tali asih dengan media; pengetahuan luas terhadap target audiens; dan publisitas yang cepat dan continue membuat rancangan dan penyelanggaraan berbagai event mereka berjalan mulus.

Strategi Public Relations terbagi menjadi sembilan langkah melalui empat fase tahapan perencanaan (Smith, 2005). Keempat tahapan tersebut dapat dilihat pada gambar 1 .

Ada beberapa faktor yang cukup penting dalam menentukan keberhasilan pelaksanaan program atau aktivitas Public Relations yaitu Communicator, Relationship, Back up Management, Good Image Maker (Ruslan, 2010:26). Melalui peran Public Relations, Sinar Mas Land membangun hubungan dengan stakeholder perusahaan melalui media online, yaitu instagram (@SatuBSD) sebagai salah satu media informatif yang dapat diakses oleh stakeholder perusahaan mengenai kegiatan perusahaan.

SATU BSD sendiri adalah program di bidang Community Development yang dicanangkan oleh Sinar Mas Land sejak tahun 2017. SATU BSD adalah singkatan dari Silaturahmi Antar Umat yang terdiri dari tiga 


\section{Penelitian Formatif}

\section{Menganalisa Situasi}

2. Menganalisa Organisasi

3. Menganalisa Publik.

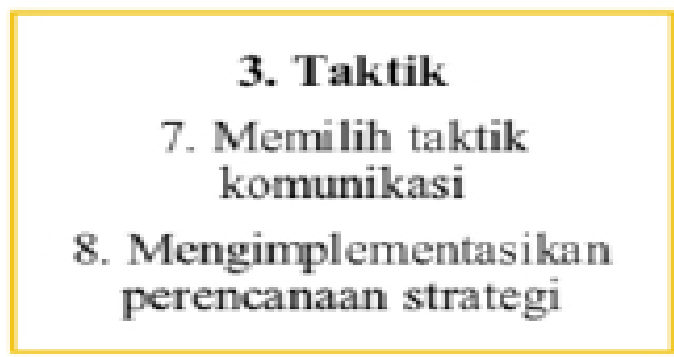

\section{Strategi}

4. Menetapkan tujuan dan sasaran

5. Menformulasikan Strategi Aksi dan Reaksi

\section{Menggunakan Komunikasi} Efektif

\section{Penelitian Evaluasi \\ 9. Mengevaluasi perencanaan strategi}

Sumber: Smith, 2005

Gambar 1 Tahapan Strategi PR menurut Ronald D Smith

pilar utama, yaitu Berdikari, Sehat, Damai yang bertujuan untuk meningkatkan rasa memiliki yang erat antar warga dan menggali potensi terkait kehadiran Kawasan BSD.

Keberhasilan tim Public Relations Sinar Mas Land dalam membangun citra merek membuat peneliti tertarik untuk melakuken penelitian dengan judul "Strategi Public Relations Sinar Mas land dalam Membangun Brand Image Perusahaan”. Tujuan penelitian ini untuk mengetahui strategi PR yang dilakukan Sinar Mas Land dalam membangun brand image perusahaan sehingga diharapkan strategi tersebut dapat menginspirasi para pebisnis muda untuk inovatif dan kreatif. Selain itu, kemampuan PR Sinar Mas Land dalam memperkenalkan merek perusahaan kepada masyarakat melalui komunikasi efektif membuat topik ini semakin menarik untuk dikaji.

\section{METODE PENELITIAN}

Paradigma postpostivisme adalah sudut pandang yang peneliti gunakan, dimana paradigma ini bertujuan untuk memperbaiki berbagai kelemanan dalam paradigma positivisme yang hanya mengandalkan kemampuan obsrvasi langsung pada objek yang diteliti (Gunawan, 2013). Melalui sudut pandang postpositivisme, peneliti melihat penelitian sebagai rangkaian logis yang meyakini perspektif dari para partisipan yang 
terlibat pada sebuah realitas tunggal, serta mendukung metode pengumpulan dan analisis data yang diteliti (Creswell, 2013).

Pendekatan kualitatif digunakan karena temuan yang ingin diteliti tidak dapat dicapai secara statistik atau dengan cara pengukuran kuantitas. Pendekatan kualitatif merupakan penelitian yang menghasilkan data deskriptif yang berkaitan dengan perilaku orang-orang yang diamati (Sujarweni, 2014). Sedangkan jenis penelitian deskriptif digunakan karena peneliti ingin menggambarkan fenomena atau peristiawa nyata tentang kasus yang diteliti.

Peneliti memilih informan dengan menggunakan teknik purposive sampling, dimana dalam menentukan informan kunci, informan pendukung, hingga informan ahli, peneliti melakukannya dengan menentukan berbagai kriteria khusus (Sujarweni, 2014). Informan kunci adalah mereka yang paham terkait dengan strategi PR di Sinar Mas Land dalam membangun brand image perusahaan, yaitu Public Relations Strategic Anisa Gita Putri. Sementara informan pendukung pada penelitian ini yaitu karyawan yang bukan berada di divisi PR tetapi masih berada di lingkungan gedung Sinar Mas Land plaza dan masyarakat umum yang mengetahui Sinar Mas Land dan berada di lingkungan the breeze $\mathrm{BSD}$, yaitu Graphic Design and PR Support SML Alfred, Media Relations Staff SML Yunila Wijaya, dan dua orang audiens pada event BBQ.

Peneliti memperoleh data dari teknik pengumpulan data yang berupa: (1) Observasi non partisipan; (2) Wawancara mendalam dengan jenis pertanyaan terbuka agar memperoleh variasi jawaban dari para informan; dan (3) Dokumentasi untuk memperkuat temuan berupa buku (literatur), data internet, dan foto yang berhubungan dengan penelitian ini. Sedangkan untuk menguji validitas data, peneliti melakukan teknik triangulasi sumber dengan mengkroscek data yang sudah diperoleh dari berbagai sumber, yaitu dari Head of Corporate Communication Sinar Mas Land Atika Sunarya. Data dari sumber yang berbeda dideskripsikan, dikategorisasikan, mana pandangan yang sama, berbeda dan mana yang lebih spesifik (Fuad \& Nugroho, 2014).

\section{HASIL DAN PEMBAHASAN}

Dari hasil observasi non-partisipan yang peneliti lakukan di Sinar Mas Land menunjukkan bahwa strategi program yang dilakukan oleh PR Sinar Mas Land dalam membangun brand image perusahaan yaitu melalui publikasi menggunakan event sebagai pendekatan soft selling kepada stakeholder internal dan eksternalnya. Strategi lainnya adalah join venture dengan perusahaan untuk membangun kampanye perusahaan yaitu ingin menjadi kawasan smart digital city. Berbagai 
kegiatan dilakukan guna memberikan pesan tersirat dengan mengedepankan pendekatan emosioanl agar nilai-nilai positif perusahaan dapat memengaruhi pikiran para calon konsumen.

Strategi PR yang diterapkan oleh Sinar Mas Land menunjukan keberhasilan dalam kegiatan PR, seperti event, campaign ataupun festival. Berikut pemaparan model yang peneliti gunakan untuk menganalisis perencanaan strategi Public Relations dalam membangun brand image.

Fase pertama dari model perencanaan Smith yaitu formative research. Pada tahap pertama dari formative research, PR Sinar Mas Land melakukan dua hal untuk menganalisa situasi yaitu melakukan sebuah riset sebanyakbanyaknya melalui bantuan agensi yang bekerja sama dengannya untuk melihat fenomena yang sedang krusial di masyarakat setiap tahunnya terutama fenomena yang memiliki keterlibatan dengan perusahaan baik itu negatif atau positif. Hasil riset tersebut dilaporkan setiap harinya kepada tim PR guna mendapatkan data yang paling pasti terhadap permasalahan yang sebenarnya terjadi di masyarakat ataupun lingkungkan perusahaan. Dengan begitu, akan terciptanya hasil keputusan yang paling baik untuk mengatasi situasi yang terjadi, sehingga feedback dari masyarakat ke perusahaan pun sesuai dengan yang diinginkan.

Kedua tim PR melakukan brainstorming yang merupakan teknik pencarian penyelesaian dari suatu masalah dengan cara menyampaikan gagasan secara spontan dalam kelompok kerja. Teknik ini dilakukan oleh tim PR untuk membicarakan mengenai konsep program tahunan yang sudah ditentukan oleh para petinggi. Contohnya, tata cara melakukan pendekatan ke khalayak agar acaranya banyak diminati oleh masyarakat dan juga cara pembagian tugas agar proses publikasi dapat merata di semua media yang bekerja sama, serta mencari tahu informasi-informasi terbaru mengenai perkembangkan perusahaan di masyarakat. Proses ketika ingin melakukan brainstorming dilakukan dengan adanya pertemuan dengan seluruh tim PR beserta kepala bagian divisi Corcom yang bertanggung jawab dalam pengambilan keputusan. Adanya kepala bagian divisi Corcom bertujuan untuk memberikan keputusan apakah program ini cocok untuk diaplikasikan ataukah sebaliknya.

Tahap kedua dari research formative adalah analisis organisasi. Analisis ini merupakan analisis yang mempengaruhi audit PR, artinya menganalisis kekuatan dan kelemahan yang dimiliki perusahaan melalui analisis SWOT dengan dipengaruhi oleh tiga aspek yaitu lingkungan internal dan eksternal, serta persepsi publik. Aspek lingkungan internal dilihat dari kesesuaian aktivitas dengan misi perusahaan dan bagaimana kinerja karyawan sebagai 
sumber daya yang dimiliki. Dalam konteks analisis SWOT, PR di Sinar Mas Land memiliki kekuatan, kelemahan, peluang, dan ancaman dalam menjalankan programnya.

Tahap ketiga dari research formatif adalah analisis publik yaitu analisis atau identifikasi stakeholder penting, baik publik internal (karyawan, keluarga karyawan, manajemen, dan investor) maupun publik eksternal (media, pemerintah, konsumen, masyarakat dan LSM) yang perlu perusahaan kenali dan memberi batasan. Selain itu, terdapat juga key public yang terlibat dalam proses komunikasi dengan organisasi.

Adanya persepsi dari stakeholder perusahaan mampu menganalisa mengenai pandangan yang akan diberikan oleh publik positif atau negatif, jika terdapat pandangan negatif untuk perusahaan akan mempengaruhi brand image perusahaan. Akan tetapi, PR Sinar Mas Land sudah mengenali dengan baik setiap stakeholders perusahaan dengan melakukan pendekatan kepada setiap publiknya agar terbangun hubungan baik. Misalnya, perusahaan memberikan fasilitas yang menguntungkan untuk para karyawan berupa mobil, uang saku dan kantor yang nyaman agar mendapatkan dukungan dari publik internal,

Sementara itu, untuk publik eksternal, perusahaan menyediakan divisi Media Relations guna memfokuskan hubungan dengan wartawan/media dan untuk menggarap konsumen. Hubungan dengan masyarakat dikelola oleh divisi PR dan Marketing Communications dengan menggunakan pendekatan pemasaran melalui pendekatan soft selling dan hard selling. Selain itu, publik eksternal lainnya seperti pemerintah dikelola oleh divisi lain yang mengurus secara mendalam mengenai persetujuhan tanah dan pembangunan melalui divisi Corporate Goverment.

Melalui setiap divisi yang ada tentunya membantu perusahaan untuk menghindari adanya persepsi negatif tersebut, maka dari itu dari kedua stakeholder tersebut, muncullah key public yaitu publik-publik yang bersedia dan antusias mengikuti program acara yang diberikan oleh perusahaan serta publik yang bersedia berkontribusi untuk acara perusahaan seperti media/wartawan. Dapat disimpulkan bahwa dengan mengetahui key public, perusahaan dapat lebih mudah memusatkan proses komunikasi mereka.

Fase Kedua yaitu fase strategi. Dalam fase strategi ditahap pertama, PR Sinar Mas Land menetapkan sasaran dan tujuan yang sesuai (inline) dengan misi perusahaan yaitu ingin membangun brand image sebagai pengembang properti terpercaya bagi masyarakat dan para pemangku kepentingan di tingkat Asia Tenggara. Sasaran yang perusahaan tentukan adalah seluruh masyarakat di Indonesia 
terutama masyarakat yang berada di sekitar kawasan BSD City. Oleh karena itu, untuk mendapatkan penerimaan yang diberikan oleh publik perusahaan membuat beberapa program yang dapat diterima oleh masyarakat. Programprogram tersebut akan peneliti jelaskan pada tahap kedua dari fase strategi.

Tahap kedua dari fase strategi adalah merumuskan strategi aksi dan respon seperti menentukan aktivitas apa saja yang dapat dilakukan pada berbagai situasi. Strategi proaktif dilakukan sesuai rencana yang telah disusun dengan tujuan agar perusahaan mampu merespon kebutuhan dan ekspektasi dari public mereka. Sedangkan strategi reaktif dilakukan ketika sudah terjadi akuisisi dimana organisasi sudah mempersiapkan posisi aktif untuk menjalankan tujuan organisasi seperti membangun sasaran, reputasi, termasuk kepercayaan di dalamnya. Oleh karena itu, pada tahap kedua fase strategi, PR Sinar Mas Land rumuskan untuk dilakukan dalam mencapai respon brand image yang diharapkan perusahaan yaitu; (1) Melakukan kegiatan publikasi melalui sebuah event yang mereka sajikan. Terdapat delapan event tahunan dimana empat di antaranya merupakan event besar yang dilaksanakan, seperti: press conference yang merupakan special event yang dibuat sebagai wadah untuk memberikan penjelasan kebijakan dengan harapan daoat diterima dengan baik oleh publik.

Acara besar yang kedua adalah kegiatan CSR (Corporate Social Responsibility) yang memiliki dua program tema yang berbeda. Program pertama bertemakan Berantas Buta Qur'an untuk semua masyarakat yang berada disekitar kawasan BSD City terutama guru-guru ngaji yang mendapatkan undangan langsung dari perusahaan. Tujuan dari acara ini yaitu untuk pemberdayaan masyarakat sekitar yang merupakan salah satu stakeholder perusahaan agar masyarakat dapat mengetahui bahwa Sinar Mas Land bukan hanya perusahaan yang mementingkan keuntungan/laba dari perusahaan melainkan ingin menanamkan kepada masyarakat bahwa perusahaan ini memberikan manfaat yang sebesar-besarnya melaui penyerapan tenaga kerja dan pembukaan lapangan pekerjaan.

Program corporate social responsibility (CSR) kedua yaitu NoBar (Nonton Bareng) yang bekerja sama dengan sekolah-sekolah di sekitar BSD, mulai dari sekolah golongan elid ataupun sekolah biasa saja yang duduk di sekolah menengah pertama (SMP). Tujuan acara tersebut ingin menghapus stigma perusahaan yang dipandang oleh masyarakat sebagai kawasan berada menjadi kawasan untuk semua golongan masyarakat. Maka dari itu khalayak acara ini, terdiri dari semua golongan kelas dimasyarakat. 
Acara besar ketiga yaitu YAC (Youth Artsitecture Competition) yang bekerja sama dengan universitas jurusan artsitektur di sekitar kawasan BSD. Tujuan acara ini untuk mencari penerus-penerus muda yang berprestasi dan inovatif serta sekaligus sebagai ajang untuk memperkenalkan terobosan baru yang disediakan oleh Sinar Mas Land yaitu kawasan DigitalHub kepada masyarakat. Kawasan tersebut berada di Bumi Serpong Damai (BSD) dan akan menjadi tempat berkumpulnya para startup company, Tech Leader, dan komunitas digital yang ada di Indonesia. Sinar Mas Land mengeluarkan konsep kawasan tersebut karena berada di jantung revolusi digital global dengan infrastruktur yang tertata baik dan luas, serta berdasarkan kebutuhan perusahaan rintisan teknologi yang membutuhkan gedung dengan konsep ramah lingkungan. Salah satu perusahaan rintisan teknologi yang sudah bergabung dan akan membuka kantornya disana adalah Apple Inc.

Publikasi tim Public relations kian pesat dalam menyebarkan informasi terkait program baru yang diberikan Sinar Mas Land kepada masyarakat. Beberapa kegiatan menarik yang diberikan PR kepada masyarakat untuk memperkenalkan merek perusahaan sekaligus program barunya yaitu melalui DigitalHub goes to campus yang bertemakan "How to be A Digipreneur", untuk mengedukasi masyarakat umum tentang industri animasi yang telah mampu menjadi peluang karir bagi insan-insan kreatif Indonesia. Jadi sebelum mengikuti acara YAC tersebut, tim PR mengadakan kunjungan ke kampus-kampus (goes to campus) untuk memberikan pembelajaran mengenai How to be A Digipreneur di dunia digital artsitektur.

Acara besar keempat yaitu, Digital Society Gethering yang bertujuan untuk membangun hubungan baik dengan para blogger dan komunitas lainnya di kawasan BSD City. Menurut tim Public Relations Sinar Mas Land, membangun hubungan yang baik dengan semua stakeholder yang ada terutama yang paling dekat dengan lingkungan perusahaan merupakan kunci penting untuk membangun gambaran masyarakat tentang perusahaan. Acara lainnya yaitu Blogger Tour yang dilakukan pada bulan yang berbeda dan tujuannya untuk memperkenalkan perusahaan lebih dalam kepada para blogger di kawasan BSD City. Ada juga acara Campus Tour yang merupakan kegiatan mengajak universitasuniversitas Indonesia untuk mengenal lebih dalam mengenai perusahaan Sinar Mas Land. Untuk event kedelapan adalah special event yang dilaksanakan pada momen tertentu di luar kegiatan rutin program kerja Public Relations, seperti pembukaan jalan baru atau menyambut acara besar seperti Asian Games 2018.

Aksi kedua dalam fase strategi tahap kedua, 
dilakukan dengan menggunakan komunikasi reaktif, dimana perusahaan melakukan akuisisi dengan perusahaan lain untuk menjalankan tujuan organisasi seperti membangun sasaran, membangun kepercayaan termasuk reputasi. PT. Bumi Serpong Damai Tbk. sudah melakukan akuisisi dengan perusahaan PT. Duta Pertiwi Tbk. pada tahun 1989, maka dengan begitu terbentuklah kesepatakan antar perusahaan yang sudah melakukan penggabungan untuk membuat brand perusahaan menjadi Sinar Mas Land. Kesepakatan tersebut bertujuan untuk mempermudah masyarakat mengenal perusahaan mereka dengan satu brand yang ditentukan, namun dalam BEJ (Bursa Efek Jakarta) tetap terdapat kedua nama perusahaan yang terdaftar yaitu PT. Bumi Serpong Damai Tbk. dan PT. Duta Pertiwi Tbk. Setelah kedua perusahaan bergabung maka terjadilah join venture dengan perusahaan lain untuk membangun brand image perusahaan yang dipercaya oleh masyarakat dan stakeholder perusahaan, serta tujuan lainnya dari aksi ini yaitu untuk membentuk sebuah reputasi perusahaan yang baik.

Brand perlu menunjukkan dan mengomunikasikan perbedaan mereka, sehingga memudahkan masyarakat memahami perbedaan suatu perusahaan dengan perusahaan lainnya (Išoraitè, 2018:4). Konsumen diyakinkan oleh logo, simbol dan merek dagang yang mereka kenal. Untuk menjadi familiar, brand perlu berkomitmen untuk ide sentral dari waktu ke waktu untuk mengatasi perubahan dan tetap dikenali. Identitas merek yang efektif memposisikan perusahaan untuk perubahan dan pertumbuhan di masa depan. Hal ini mendukung strategi pemasaran yang berkembang.

Aksi kedua yang dilakukan tim PR adalah mengadakan join venture dengan perusahaan di bidang bisnis teknologi dan bidang pendidikan untuk mencapai kerja sama yang saling memberikan keuntungan. Join venture dengan perusahaan bisnis swasta, contohnya Apple Inc dan Grab yang sedang bekerja sama saat ini, bertujuan untuk meningkatkan campaign perusahaan yaitu ingin mengembangkan kawasan BSD City menjadi kawasan Smart Digital City yang ramah lingkungan. Sementara untuk join venture dengan bidang Pendidikan, Sinar Mas Land memberikan terobosan berupa penawaran mengenai beasiswa coding kepada universitas di sekitar kawasan BSD City, karena menurut hasil riset tim PR menyatakan bahwa saat ini anak muda penerus bangsa Indonesia sedang membutuhkan program tersebut terlihat dari terpaan jaman yang mendorong masyarakat untuk berinovatif dalam penggunaan teknologi digital.

Tahap ketiga dari fase strategi yaitu menggunakan komunikasi yang efektif dengan memberlakukan publik sebagai audiens. 
Agar tercipta komunikasi efektif maka perlu dipetakan terlebih dahulu pesan apa yang akan disampaikan, bagaimana struktur dan tampilan pesannya, simbol-simbol yang akan diterapkan, hingga siapa yang menyampaikan dan melalui media apa. Isi pesan presentasi dipersiapkan oleh anggota PR yaitu Anisa Gita selaku Strategic Public Relations, kemudian persetujuan akan ditangani oleh atasan. Pesan akan disampaikan oleh tokoh penting sebagai tamu undangan yang memiliki keahlihan dalam bidangnya, sehingga pesan yang disampaikan olehnya akan mudah dipercaya oleh audiens.

Fase ketiga yaitu fase taktikyang merupakan pendekatan terencana dengan pertimbangan berbagai taktik komunikasi yang untuk mencapai tujuan. Tahap pertama yaitu pemilihan taktik komunikasi dilihat berdasarkan empat aspek yaitu: (1) interpersonal komunikasi, yaitu proses pertukaran informasi secara pribadi secara tatap muka yang biasanya diterapkan pada acara-acara special perusahaan; (2) organisasi media, yang bertugas mengontrol konten pesan mulai dari tahap produksi hingga distribusinya. Bentuk media yang diproduksi seperti bulletins, newsletter, letter, annual reports, dan direct email); (3) media baru, sebagai wadah bagi perusahaan untuk menyadikan pesan yang kredibel, seperti melalui newspaper and Computer Based Media; (4) iklan dan promosi media, bertujuan untuk menjangkau khalayak yang lebih luas lagi.

Aspek pertama dalam tahap fase taktik pertama yaitu melakukan interpersonal komunikasi dengan media/wartawan melalui acara spesial yang disajikan oleh tim media relations. Beberapa acara yang disajikan oleh tim Media Relations yaitu seperti acara bonding dengan wartawan, mengadakan coffee break bersama, dan mengundang wartawan untuk berkunjung ke perusahaan. Sementara kegiatan interpersonal komunikasi yang dilakukan oleh PR Sinar Mas Land kepada publik yaitu melakukan pendekatan kepada publik dengan menggunakan konsep QOL (Quality of Live) yang merupakan istilah yang digunakan untuk mengukur kesejahteraan. Berdasarkan hasil riset yang dilakukan oleh Shamsan (2015:10) menunjukkan bahwa media relations terlihat memiliki dampak yang sangat besar pada pekerjaan Public Relations. Oleh karena itu, ini berarti bahwa apa pun yang akan dikomunikasikan di media atau apa pun yang telah dikomunikasikan oleh media cenderung membingkai cara manajemen bank membingkai pesan komunikasi.

Tugas yang rumit dan menantang adalah mengembangkan, mengelola, dan memelihara hubungan yang baik dengan media (Neha \& Ram, 2017:166). Penting untuk berkomunikasi secara bijaksana dengan media berita ketika mencari publisitas atau menanggapi pertanyaan 
wartawan. Ini juga melibatkan pengaturan dan mempertahankan hubungan kerja yang profesional dan saling menguntungkan dengan pengumpul berita dan penjaga gerbang.

Indikator standar QOL meliputi lingkungan sosial, kesehatan fisik dan mental, Pendidikan, rekreasi, dan hak untuk bersosial. Maka dari itu pada fase strategi sebelumnya, PR Sinar Mas Land selalu melaksanakan berbagai acara yang mampu memenuhi indikator standar dari konsep QOL yang mereka gunakan. Contohnya kegiatan CSR untuk memenuhi kebutuhan lingkungan sosial dan acara YAC (Youth Artsitecture Competitions) yang berfokus untuk mengembangkan pendidikan di dunia artsitektur Indonesia. Pendekatan QOL ini sukses digunakan oleh PR Sinar Mas Land dalam memperkenalkan keberadaan perusahaan kepada publiknya. Kesuksesan pendekatan ini dilihat dari kesadaran masyarakat terhadap brand Sinar Mas Land dan tanggapan positif yang diberikan masyarakat mengenai image perusahaan.

Aspek kedua dalam fase taktik pertama adalah organisasi media, yang dimiliki Sinar Mas Land untuk mengontrol konten pesan dan waktu, serta pengemasan pendistribusian untuk diterbitkan. Organisasi media dikontrol oleh salah satu tim PR yaitu Haris Maulaya selaku Media Monitoring dan PR Support di Sinar Mas Land. Media platform yang dikelolah dan difokuskan mengenai konten yang akan disajikan adalah konten media sosial seperti Facebook, Instagram, dan Twitter. Konten media tersebut berupa informasi-informasi seputar kawasan di BSD mengenai perumahan baru, fasilitasi baru seperti Stasiun Cisauk dan pasar modern intermoda yang dikelolah oleh Sinar Mas Land, festival dan workshop yang diadakan di BSD City serta perlombaan basket. Adapun konten mengenai informasi mengenai tempat-tempat yang bagus untuk dikunjungi sebagai wisata seperti Ocean Park, The Brezze, Q-Biq.

Agar konten media tersebut mendapatkan perhatian dari masyarakat, maka taktik yang digunakan oleh PR adalah melakukan berbagai Quiz untuk publik dengan hadiah berupa voucher gratis untuk mengakses wisata/ fasilitas yang ada di BSD. Kemudian untuk pengolahan waktu biasanya konten tersebut akan di upload ke media pada jam sibuk, karena berdasarkan hasil riset, pada saat traffic jam orang-orang sering menggunakan handphone untuk mencari atau melihat-lihat informasi yang ada di media online dan media sosial.

Tidak hanya itu, tim PR juga melakukan media monitoring setiap hari melalui agency riset yang bekerja sama dengan perusahaan. Tujuan dari media monitoring ini adalah untuk mengetahui jika adanya informasi-informasi yang tidak sesuai dengan misi perusahaan 
atau penyimpangan pesan. Sehingga dari hasil riset tersebut, PR dapat mempersiapkan taktik untuk menanggapi pesan yang ada di masyarakat melalui stand by statement yang dipersiapkan oleh tim PR, yaitu pernyataan langsung yang dipersiapkan oleh tim PR untuk disampaikan kepada masyarakat melalui media massa. Tujuannya untuk melakukan konfirmasi pesan yang sebenarnya terjadi kepada publik mengenai pesan yang menjadi isu beredar dibicarakan di media. Melalui Stand by Statement tersebut mampu memberikan kejelasan kepada masyarakat terkait isu yang beredar untuk menghilangkan rasa gelisah dan penasaran masyarkat.

Aspek ketiga dalam fase taktik pertama adalah media baru yang disajikan untuk mempresentasikan pesan yang kredibel. Berdasarkan penjelasan diatas tentunya Sinar Mas Land mensajikan media baru untuk masyarakat mengakses informasi seputar perusahaan dan produk lainnya. Semua media baru yang disajikan menggunakan nama pengguna/username satubsd yang artinya adalah Silatuhrahmi Antar UmaT Berdikari Sehat dan Damai.

Aspek keempat dalam fase taktik pertama adalah iklan dan promosi media, PR Sinar Mas Land melakukan kegiatan promosi soft selling melalui berbagai program event yang disediakan oleh perusahaan, sementara untuk iklan tentunya difokuskan oleh divisi Marcomm yang bertugas untuk memasang iklan di media, billboard, jalan raya, dan membukan booth diacara tertentu, mencetak media periklanan seperti majalah, koran, iklan direktori, iklan elektronik; televisi, radio, komputer. Untuk iklan luar ruangan seperti poster, kostum kantor, aksesoris, dilakukan oleh salah satu tim PR yang berada dibagian Graphic Design and PR Support untuk membuat sebuah konsep design yang sesuai dengan program perusahaan, kemudian proses printing aksesoris tersebut diserahkan kepada vendor yang sudah bekerja sama. Promosi adalah salah satu hal penting dalam proses pemasaran (Poerwadi et al., 2019). Penekanan pada biaya promosi harus diseimbangkan dengan strategi promosi yang mampu bersaing. Selain promosi, kualitas pesaing juga memengaruhi strategi perluasan brand.

Fase taktik tahap kedua adalah mengimplementasikan perencanaan strategi berdasarkan kelima aspek yaitu aspek pertama yaitu: (1) Item personil yang merupakan pembuatan anggaran berdasarkan jumlah orang dan waktu yang dibutuhkan agar dapat mencapai hasil dari taktik yang diharapkan. Contohnya, pada tahap perencanaan, desain fotografi; (2) aspek kedua adalah material dalam anggaran termasuk hal-hal yang berkaitan dengan taktik; (3) aspek ketiga adalah biaya media khusus 
untuk pembelian waktu dan ruang yang terkait dengan taktik iklan; (4) aspek keempat adalah peralatan dan fasilitas termasuk dalam modal anggaran untuk belanja peralatan seperti komputer, desktop scanner, dan printer; (5) Fase taktik tahap kedua berdasarkan aspek kelima adalah barang administrasi merupakan anggaran termasuk untuk klaim telepon.

Fase terakhir adalah Fase Penelitian Evaluatif yang menunjukkan tingkat keberhasilan dari program atau event yang telah terselenggara. Hingga pada akhirnya, tim PR akan mudah menentukan hal apa saja yang perlu diperbaiki, dimodifikasi, atau mungkin ditingkatkan. Di Sinar Mas Land tentunya Public Relations melalukan fase penelitian evaluatif sebelum acara dimulai dan setelah acara yang dilaksankan selesai. Jadi terdapat dua evaluasi yang dilakukan oleh tim PR yaitu evaluasi di awal sebelum acara mulai dengan melakukan perbandingan anggaran yang akan keluar dari tahun sebelumnya dengan tahun sekarang, apakah dengan anggaran yang lebih besar untuk tahun ini membantu acara menjadi lebih baik atau sebaliknya menjadi tidak efisien.

Sementara untuk evaluasi setelah acara selesai, terdapat dua kegiatan yang dilakukan oleh tim Public Relations dan tim lainnya yang membantu acara tersebut yaitu: (1) Melakukan teknik FGD (Focus Group Discussion) dengan tim internal PR untuk membahas mengenai kekurangan dan kelebihan dari hasil implementasi taktik yang dilakukan. Proses FGD dilakukan setelah acara yang dilaksanakan selesai dengan didampingi oleh moderator yang bertugas sebagai pemimpin pembicara untuk menentukan keputusan akhir dari hasil diskusi. Biasanya yang menjadi moderator dalam FGD adalah ketua dari tim PR itu sendiri yaitu Atikah Sunarya.

Menurut tim PR di Sinar Mas Land Teknik FGD ini merupakan Teknik yang paling cocok digunakan untuk berdiskusi mengenai kesuksesan sebuah acara karena dengan melakukan teknik ini, tim PR menjadi tahu apa saja kekurangan dari event tersebut dan hal apa saja yang harus dipertahankan dari event tersebut untuk kedepannya; (2) Melakukan riset kecil kepada wartawan dan beberapa audiens dengan menggunakan teknik wawancara mendalam. Tujuan dari teknik wawancara mendalam tersebut adalah untuk menanyakan mengenai keberhasilan acara tersebut dan value dari acara tersebut apakah dapat tersampaikan dengan baik atau tidak. biasanya wawancara mendalam dilakukan oleh wartawan yang hadir dengan mengajak makan bersama untuk berdiskusi.

Kegiatan wawancara mendalam dengan wartawan ditangani oleh divisi Media Relations dari awal hingga akhir. Tim Media Relations akan menemani wartawan makan bersama sambal 
berdiskusi mengenai acara tersebut yang telah selesai dilaksanakan, kemudian perwakilan dari pihak perusahaan yaitu Panji Himawan selaku Head Dvision of Corcom akan memberikan sebuah cinderamata kepada wartawan sebagai simbol terima kasih dan kenang-kenangan. Adapun beberapa audiens yang dipilih sebagai perwakilan dari setiap komunitas, kampus, dan sekolah yang hadir menjadi audiens untuk melakukan wawancara mendalam bersama anggota PR Sinar Mas Land setelah acara selesai. Kegiatan wawancara mendalam yang dilakukan kepada audiens dilaksanakan dengan cara memilih secara acak beberapa perwakilan dari audiens yang hadir. Tujuannya untuk mengetahui feedback dari responden mengenai pandangan mereka terhadap acara tersebut, apakah acaranya bermanfaat untuk mereka atau justru sebaliknya.

Berdasarkan hasil analisa peneliti di atas, terdapat persamaan tak serupa terhadap hasil penelitian peneliti dengan salah satu penelitian terdahulu yang yang berjudul "Using Pubic Relations Tools to Build Image of Tertiary Institutions". Penelitian terdahulu tersebut menyatakan bahwa PR merupakan alat yang digunakan organisasi untuk melakukan publikasi kepada masyarakat dengan menggunakan strategi event dan website (Agyapong, Twum, \& Augustine, 2015). Dalam hasil analisa peneliti menyatakan bahwa proses publikasi yang dilakukan perusahaan Sinar Mas Land untuk memperkenalkan dan membangun brand image perusahaan kepada masyarakat melalui delapan program event yang dibuat oleh tim PR dan program Join Venture dengan perusahaan besar yang dilakukan setiap tahunnya mampu membangun brand image perusahaan yang sesuai dengan misi perusahaan yaitu ingin menjadikan Sinar Mas Land sebagai perusahaan pengembang properti terpercaya di Asia Tenggara yang dipercayai oleh masyarakat dan stakeholdernya.

Berdasarkan hasil analisa penelitian ini menyatakan bahwa PR memiliki fungsi dan peranannya dalam sebuah perusahaan serupa dengan kajian teori yang disampaikan oleh Lawrence D. Brennan bahwa terdapat empat peranan PR dalam perusahaan yang sudah peneliti jelaskan dalam bab empat hasil penelitian (Ruslan, 2010:26). Keempat peranan PR tersebut, diaplikasikan oleh perusahaan Sinar Mas Land dalam menjalankan susunan program PR untuk membangun brand image perusahaan. Peran PR di Sinar Mas Land yaitu: (1) sebagai komunikator untuk stakeholder perusahaan; (2) melakukan publikasi; (3) melaksanakan kegiatan Corporate Social Responsibility (CSR); dan (4) membangun image program perusahaan.

Dalam menjalankan peranan di atas, tentu PR memiliki program-program tahunan yang 
harus mereka lakukan untuk mencapai visi dan misi perusahaan. Aktivitas yang dilakukan PR berdasarkan dari hasil penelitian peneliti tersebut menyatakan bahwa tujuan program PR di Sinar Mas Land adalah untuk membangun brand image perusahaan yang dipercaya oleh masyarakat dan stakeholdernya. Melalui teori yang dikemukakan oleh Smith mengenai tahapan perencanaan strategi PR, keempat tahapan tersebut telah dilakukan oleh PR perusahaan Sinar Mas Land mulai dari tahap pertama yaitu riset formatif yang dilakukan dengan mencari fakta data di lapangan melalui riset dan brainstorming; tahap kedua yaitu fase strategi dengan menentukan tujuan dan sasaran untuk menjalankan aksi publikasi melalui sebuah event serta melakukan aksi Join Venture dengan perusahaan lain; tahap ketiga yaitu fase taktik dengan melakukan bonding dengan wartawan untuk menjalin hubungan harmonis dengan media massa dan juga melakukan pendekatan dengan masyarakat melalui pendekatan Quality of Life (QOL) yang merupakan pendekatan berdasarkan aspek perasaan, sosial, dan fisik dalam kehidupan individu. Penilaian dari pendekatan ini atas kesejateraan mereka atau ketiadaannya.

Selain itu, taktik yang digunakan oleh PR Sinar Mas Land yaitu melakukan media monitoring terhadap berita-berita yang terdapat di media massa, apakah pesan yang diterbitkan merupakan berita baik atau buruk. Tujuan dari media monitoring adalah untuk mengatur pesan yang disampaikan oleh perusahaan agar sesuai diterima oleh masyarakat, apabila terjadi berita buruk maka pihak perusahaan akan melakukan konfirmasi segera kepada pihak media mengenai kronologi informasi yang sebenarnya melalui perwakilan dari kepala divisi President Office Sinar Mas Land dan akan disediakan stand by statement oleh tim PR untuk perwakilan perusahaan dalam menyampaikan informasi yang sebenarnya.

Tujuan dari stand by statement tersebut yaitu membantu pihak perusahaan untuk menyampaikan informasi yang diperbolehkan disampaikan untuk media dan masyarakat. Selain hal tersebut, PR Sinar Mas Land juga menyediakan media baru yang difokuskan pada media sosial seperti Instagram, Twitter dan Facebook untuk melakukan branding perusahaan kepada masyarakat dengan memberikan informasi yang informatif serta penawaran menarik yang dapat diikuti oleh masyarakat seperti kegiatan wahana baru yang disediakan oleh perusahaan, kegiataan seminar yang diadakan oleh perusahaan, perlombaan dan juga fasilitas-fasilitas baru yang disediakan oleh perusahaan di kawasan BSD City.

Tahap terakhir yaitu fase penelitian evaluatif dengan melakukan pra-evaluasi berupa comparison budget acara yang akan 


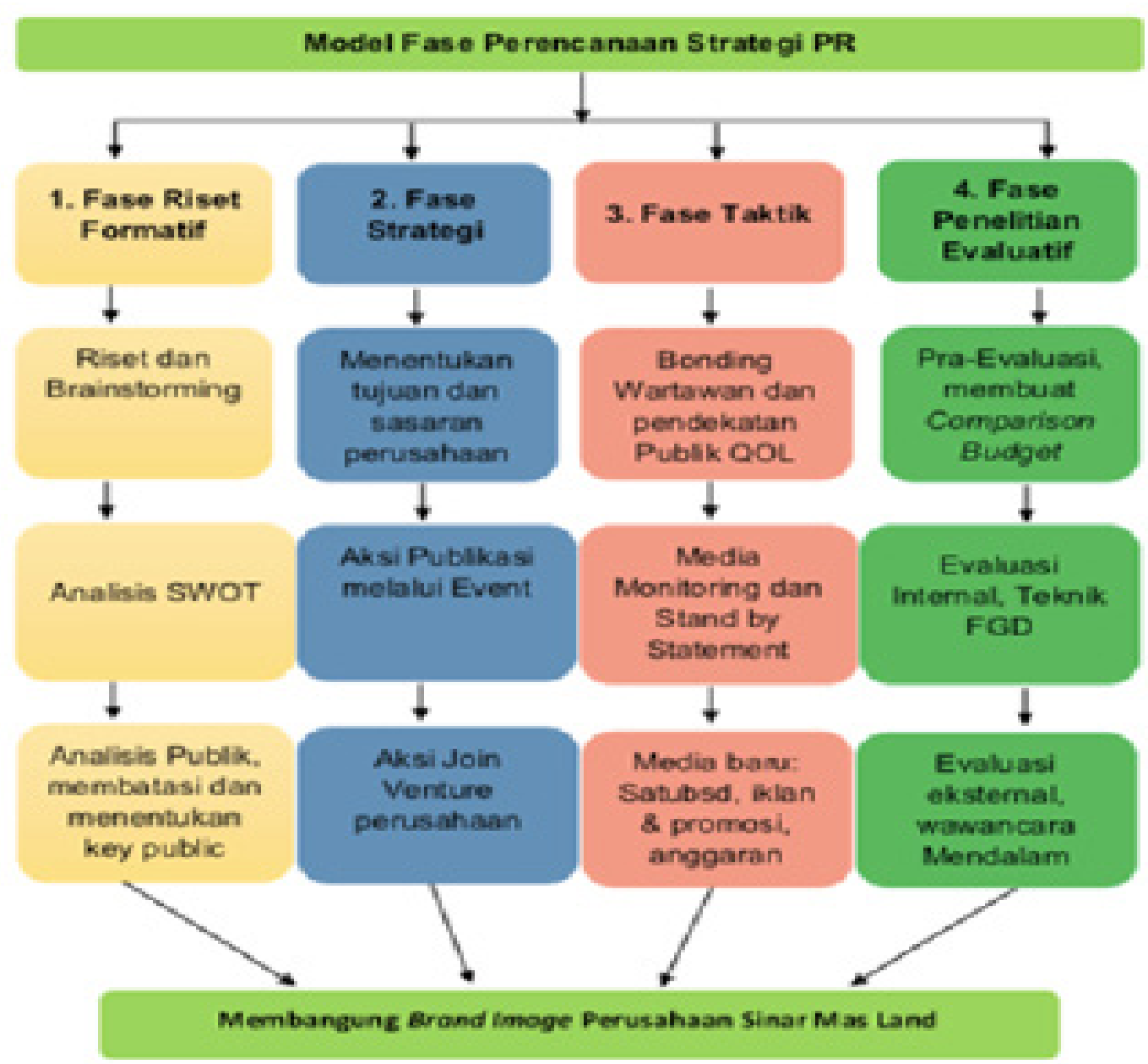

Sumber: Hasil Penelitian, 2019

\section{Gambar 2 Model Pelaksanaan Strategi PR Sinar Mas Land dalam Membangun Brand Image}

dilaksanakan oleh tim PR untuk mendapatkan persetujuan dari atasan mengenai dana yang dikeluarkan secara transparan, setelah itu tim PR juga melakukan evaluasi internal dengan teknik FGD (Focus Group Discussion) untuk mengetahui kesuksesan atau kekurangan dari acara yang mereka laksanakan serta melakukan evaluasi eksternal dengan teknik wawancara mendalam kepada beberapa wartawan yang hadir serta masyarakat yang menjadi audiens dalam acara tersebut. Tujuan dari evaluasi eksternal yaitu untuk mengetahui kepuasan yang dirasakan oleh pihak luar serta masukan yang ingin mereka sampaikan untuk perusahaan. Selain itu, hal penting dari proses evaluasi eksternal ini adalah untuk mengenal secara lebih dalam kepada pihak luar perusahaan sehingga hubungan perusahaan dengan pihak luar dapat terus terjalin dengan hangat dan baik.

Dari keempat tahapan tersebut menunjukkan bahwa benar saat ini Sinar Mas Land telah dikenal memiliki brand image positif 
di mata investor, regulator, dan konsumen. Hasil tersebut terlihat melalui riset daily monitoring 2018 yang dilakukan oleh perusahaan. Sinar Mas Land mendapatkan julukan perusahaan properti di Indonesia yang memiliki banyak kontribusi kepada negara dan dipercaya oleh masyarakat serta stakeholdernya.

\section{SIMPULAN}

Susunan strategi PR Sinar Mas Land dalam membangun brand image perusahaan dilakukan melalui proses empat tahapan pelaksanaan strategi PR yang dikemukakan oleh Smith yaitu (1) tahap pertama adalah fase research formative yang dipengaruhi oleh tiga aspek yaitu analisis situasi dengan cara memperbanyak riset dan brainstorming dengan tim PR; (2) tahap kedua adalah fase strategi yang dipengaruhi oleh tiga aspek, yaitu menentukan tujuan dan sasaran perusahaan yang inline dengan misi perusahaan, melakukan aksi dan respon dengan publikasi melalui event dan megadakan join venture; (3) tahap ketiga adalah fase taktik dengan melakukan bonding dengan wartawan dan pendekatan publik melalui konsep QOL (Quality Of Live), kemudian melaksanakan organisasi media dengan media monitoring dan menyediakan media baru yang berfokuskan di media sosial dengan nama pengguna (username) satubsd seperti; Facebook, Twitter, dan Instagram. PR juga melakukan promosi soft selling dengan mengadakan program event dan Marcom melakukan iklan melalui pemasangan billboard di jalan yang lokasinya sering mengalami jam sibuk. Tahap terakhir adalah taktik. PR membuat anggaran yang diperlukan untuk menjalankan programnya; (4) Tahap keempat yaitu penelitian evaluatif terdiri dari dua tahap yaitu pra-evaluasi dilakukan dengan membuat comparison budget dari tahun sebelumnya dengan tahun sekarang. Kemudian tahap evaluasi dilakukan dengan teknik FGD (Focus Group Discussion) oleh internal tim PR dan melakukan teknik wawancara mendalam untuk evaluasi eksternal kepada wartawan dan salah satu audiens sebagai tamu undangan. Dari keempat tahap di atas, menghasilkan sebuah brand image yang diinginkan perusahaan, yaitu menjadi perusahaan pengembang properti terpercaya yang dipercayai oleh masyarakat dan stakeholder perusahaan.

Saran yang peneliti dapat sampaikan, yaitu:

(1) Sinar Mas Land perlu mempersiapkan penawaran inovatif mengenai munculnya kebijakan baru yang dibuat oleh pemerintah untuk menggarap mangsa pasar yang lebih banyak dan perlu memperbaiki produktivitas manajemen waktu dalam proses pembangunan perumahan baru ataupun fasilitas baru yang ingin ditawarkan, menjadi lebih tepat waktu 
sehingga tidak ada lagi keterlambatan waktu dalam memperluas pembangunan di kawasan baru; (2) Bagi masyarakat, khususnya pebisnis yang bergerak dibidang properti, sebaiknya menetapkan divisi PR di perusahaan untuk membuat pelaksanaan strategi PR seperti Sinar Mas Land dalam mengembangkan brand image perusahaan, sehingga visi dan misi perusahaan dapat terealisasikan dengan baik dan juga bisa dipercaya oleh masyarakat; dan (3) Bagi masyarakat khususnya masyarakat di kawasan BSD City, yang menjadi stakeholder eksternal perusahaan diharapkan mampu memanfaatkan peluang yang ditawarkan oleh perusahaan Sinar Mas Land seperti lapangan pekerjaan dan kawasan yang inovatif.

\section{DAFTAR PUSTAKA}

Agyapong, K., Twum-Ampomah, M. K., \& Acheampong, A. (2015). Using public relations tools to build image of tertiary. International Research Journal of Marketing and Economics, 2(5), 1-18. https://www.researchgate.net/ publication/304782476_using_public_ relations_as_a_management_tool_in_ tertiary_institutions

Creswell, J. W. (2013). Penelitian kualitatif dan desain riset. Yogyakarta: Pustaka Pelajar.

Fuad, A., \& Nugroho, K. S. (2014). Panduan praktis penelitian kualitatif. Graha Ilmu.

Gunawan. (2013). Metode penelitian kualitatif teori \& praktik. Jakarta: Bumi Aksara.

Išoraite, M. (2018). Brand image development. ecoforum, 7(1). https://core.ac.uk/ download/pdf/236086742.pdf

Neha Singh, A. R. P. (2017). Role of public relations in image management of an organization. International Journal of Advance Research, Ideas and Innovation in Technology, 3(4), 164-168. https://www. ijariit.com/manuscripts/v3i4/V3I4-1183. pdf

Okazaki, S., Mueller, B., \& Taylor, C. R. (2010). Global consumer culture positioning: testing perceptions of soft-sell and hardsell advertising appeals between U.S. and Japanese consumers. Journal of International Marketing, 18(2), 20-34. https://doi.org/10.2307/20720463

Poerwadi, S., Suyanto, M., Hidayat, A., Purwadi, P., \& Eq, Z. M. (2019). Influence of brand extention strategy, brand image and brand trust on coffee product's brand equity. International Journal of Marketing Studies, 11(3), 26. https://doi.org/10.5539/ ijms.v11n3p26

Putri, N. E., Hakim, N., \& Yamin, M. (2016). Ecologicall footprint and biocapacity analysis for flooding prevention in south Sumatera. Jurnal Mimbar, 32(1), 58-64.

Raweh Mohamed Shamsan, M. O. (2015). Effects of strategic public relations on organization performance: a case study of kenya red cross society. International Journal of Scientific and Research Publications, 5(9), 1-12. http://www.ijsrp. org/research-paper-1015.php?rp=P464694

Ruslan, R. (2010). Manajemen public relations \& media komunikasi. Jakarta: Raja Grafindo Persada.

Smith, R. D. (2005). Stategic planning for public relations. Lawrence Erlabaum Associates, Inc.

Soleh Soemirat, E. A. (2010). Dasar-dasar public relations. Bandung: Remaja 
Rosdakarya.

Sujarweni, V. W. (2014). Metodelogi penelitian (lengkap, praktis, dan mudah dipahami). Yogyakarta: Pustaka Baru.

Susilowati, L., \& Sumarto, S. (2010). Membangun brand loyalty melalui brand trust dan customer satisfaction. Jurnal Riset Ekonomi Dan Bisnis, 10(1), 53-61. http://ejournal.upnjatim.ac.id/index.php/ rebis/article/view/29

Swasty, W. (2016). Branding memahami dan merancang strategi merek. Bandung: Remaja Rosdakarya Offset.

Tjiptono, F. (2014). Branding \& brand longevity. Yogyakarta: ANDI

Wijaya, B. S. (2009). Development model of marketing capabilities and export performance of smes: a proposed study. European Journal of Business and Management, 10(22), 107-114. https://doi. org/10.13140/ejbm.2013.55.65 